\title{
PENGARUH DISIPLIN KERJA DAN LINGKUNGAN KERJA TERHADAP KINERJA KARYAWAN PT. BANK BCA KCP CITRA TOWERS KEMAYORAN
}

\author{
Nurman Ibrahim 1) \\ 1) Mahasiswa Program Studi Manajemen FE UNKRIS \\ Eddy Sanusi. S ${ }^{2)}$ \\ 2) Dosen Program Studi Manajemen FE UNKRIS \\ Alamat: Kampus UNKRIS, Jatiwaringin Jakarta Timur \\ Email : eddy.sanusi23@gmail.com
}

\begin{abstract}
To determine the effect of work discipline and work environment on employee performance PT. Bank BCA KCP Citra Towers Kemayoran. This research is included in the category of causal associative research using a quantitative approach. The population in this study were all employees of PT. Bank BCA KCP Citra Towers Kemayoran, amounting to 30 people. The sample uses a saturated sampling technique, all members of the population are sampled, because the relative number is small, while the data analysis method uses partially and simultaneous linear regression. The results showed that partially or simultaneous work discipline and work environment had a positive and significant effect on the performance of the employees of PT. Bank BCA KCP Citra Towers Kemayoran.
\end{abstract}

Keywords: Work discipline, work environment and employee performance

\section{PENDAHULUAN}

Sumber daya manusia merupakan tulang punggung kehidupan organisasi, keberhasilan organisasi secara keseluruhan sangat bergantung pada sumber daya manusia untuk mencapai tujuan organisasi. Karena itu, perusahaan/isntansi harus memiliki karyawan yang memiliki kedisiplinan yang tinggi, berkemampuan, memiliki banyak pengalaman dan berprestasi. Selain itu, sumber daya manusia juga memiliki pengetahuan, keterampilan, karya dan masih banyak potensi potensi yang dimiliki. Bagaimanapun majunya tekhnologi, berkembangnya informasi tanpa adanya sumber daya manusia maka tujuan tersebut tidak akan tercapai.

Di samping itu semakin berkembangnya teknologi, pendidikan disertai pertumbuhan ekonomi yang semakin meningkat, maka para pelaku- pelaku yang bergelut dibidang ekonomi, perbankan maupun bidang lainya ini dapat mempengaruhi tujuan perusahaan yang akan dicapai kedepannya. Salah satu upaya yang harus dilakukan dalam menghadapi tantngan global yang terjadi saat ini baik dari dalam maupun luar, tentunya dengan menyiapkan sumber daya manusia yang memiliki kompetensi dan berkualitas.

Pentingnya sumber daya manusia dalam suatu organisasi maka diperlukan pengawasan terhadap kinerja karyawan dan penyediaan fasilitas penunjang untuk meningkatkan kinerja karyawan. Kinerja karyawan yang memiliki potensi tinggi sangat dibutuhkan oleh perusahaan, mengingat kinerja karyawan merupakan penggerak tercapainya tujuan dari perusahaan. Karyawan dapat dikatakan berprestasi apabila disiplin kerja baik dan 
dapat memberikan pelayanan maksimal dan tidak adanya keluhan keluhan dari nasabah mengenai pelayanan yang telah diberikan oleh pihak bank.

Mengoptimalkan sumber daya manusia menjadi fokus utama organisasi dalam meningkatkan kinerja. Sehingga dapat dikatakan bahwa sumber daya manusia menjadi faktor kunci dalam rangka memperoleh kinerja yang baik. "Agar organisasi berfungsi secara efektif dan sesuai dengan sasaran organisasi, maka organisasi harus memiliki kinerja karyawan yang baik yaitu dengan melaksanakan tugas-tugasnya dengan cara yang handal". (Simamora, 2012).

Untuk menghasilkan kinerja yang lebih baik lagi, pihak manajer harus mengadakan evaluasi kerja setiap tahunya. Hubungan positif antara karyawan dan manajer dapat diukur melalui kehidupan sehari-hari dalam perusahaan, kinerja karyawan dari perusahaan dapat dilihat dari seberapa besar peran atau sumbangsih individu terhadap perkembangan dalam perusahaan. Kemudian akan mempengaruhi keberhasilan, tujuan, dan sasaran yang telah ditentukan perusahaan sebelumnya. Kinerja karyawan tidak akan meningkat tanpa adanya disiplin kerja, karena disiplin kerja merupakan bagian yang sangat penting untuk meningkatkan kinerja karyawan. Bagi perusahaan, adanya disiplin kerja akan menjamin terpeliharanya tata tertib dan kelancaran pelaksanaan kerja perusahaan, sehingga mendapat hasil yang optimal. Sedangkan adanya disiplin kerja bagi karyawan yaitu memberikan dampak suasana kerja yang menyenangkan sehingga akan menambah semangat dalam melaksanakan pekerjaannya.

Disiplin akan membuat diri seseorang dapat membedakan hal-hal yang wajib dilakukan dan tidak seharusnya dilakukan. Selain kedisiplinan PT. Bank BCA KCP Citra Towers Kemayoran Juga harus memperhatikan lingkungan kerja karyawan agar karyawan dapat bekerja secara efektif dan efesien, karena lingkungan kerja dapat mempengaruhi seseorang dalam melaksanakan tugas yang dibebankan baik secara langsung maupun tidak langsung.

Lingkungan kerja yang baik dan nyaman dapat meningkatkan kinerja para karyawan yang berdampak akan bermanfaat bagi perusahaan, dan seperti yang disampaikan Ishak dan Tanjung (2013) manfaat lingkungan kerja adalah "menciptakan gairah kerja, sehingga produktivitas dan prestasi kerja meningkat". lingkungan kerja yang nyaman dapat meningkatkan mempengaruhi kinerja karyawan agar dalam pelaksanaan tugasnya dapat di kerjakan secara optimal, sehat, aman dan kenyamananya terjaga. Lingungan kerja sebagai salah satu faktor utama yang menentukan karyawan bekerja secara optimal, dengan adanya lingkungan kerja yang nyaman, aman, dan tenang dapat meningkatkan kinerja karyawan dalam pencapaian tujuan. Apabila lingkungan kerja kurang menarik dan kurang memuaskan maka kondisi ini dapat menurunkan produktifitas kerja karyawan, begitu pula sebaliknya apabila lingkungan kerja kondusif maka dapat meningkatkan produktifitas kerjanya. Lingkungan kerja sangat mempengaruhi kinerja karyawan, lingkungan kerja yang menyenangkan akan mewujudkan tercapainya maksud dan tujuan perusahaan yang telah direncanakan sebelumnya.

PT. Bank BCA berdiri sejak 1957, kami hadir di tengah masyarakat Indonesia dan tumbuh menjadi salah satu bank terbesar di Indonesia. Selama lebih dari 63 tahun kami tak pernah berhenti menawarkan beragam solusi perbankan yang menjawab kebutuhan finansial nasabah dari berbagai kalangan. Melalui beragam produk dan layanan yang berkualitas dan tepat sasaran, solusi finansial $\mathrm{BCA}$ mendukung perencanaan 
keuangan pribadi dan perkembangan nasabah bisnis. Didukung oleh kekuatan jaringan antar cabang, luasnya jaringan ATM, serta jaringan perbankan elektronik lainnya, siapa saja dapat menikmati kemudahan dan kenyamanan bertransaksi yang ditawarkan BCA.

Sesuai dengan komitmen "Senantiasa di Sisi Anda", kami akan terus berupaya menjaga kepercayaan dan harapan nasabah serta para pemangku kepentingan. Memenangkan kepercayaan untuk memberikan solusi terbaik bagi kebutuhan finansial para nasabah adalah suatu kehormatan dan kebanggaan bagi BCA. Melalui perjalanan yang sudah lama dan berkomitmen senantiasa di sisi anda, maka Bank BCA selalu menjaga tingkat kedisiplinan para karyawan serta memberikan fasilitas yang bagus dengan memperhatikan lingkungan karyawan bekerja.

Tujuan penelitian adalah untuk mengetahui pengaruh disiplin kerja dan lingkungan kerja terhadap kinerja karyawan PT. Bank BCA KCP Citra Towers Kemayoran.

\section{LANDASAN TEORI}

\section{Disiplin Kerja}

Disiplin kerja suatu sikap dan perilaku seseorang yang menunjukkan ketaatan, kepatuhan, kesetiaan, keteraturan dan ketertiban pada peraturan perusahaan atau organisasi dan normal sosial yang berlaku. Bagi perusahaan, adanya disiplin kerja akan menjamin terpeliharanya tata tertib dan kelancaran pelaksanaan kerja perusahaan, sehingga mendapat hasil yang optimal. Sedangkan adanya disiplin kerja bagi karyawan yaitu memberikan dampak suasana kerja yang menyenangkan sehingga akan menambah semangat dalam melaksanakan pekerjaannya.

Menurut Hasibuan, (2017) disiplin kerja adalah "kesadaran dan kesediaan seseorang menaati semua peraturan dan norma-norma sosial yang berlaku". Kesadaran adalah sikap seseorang yang secara sukarela menaati semua peraturan dan sadar akan tugas dan tanggung jawabnya, kesediaan adalah suatu sikap dan tingkah laku dalam melaksanakan peraturan perusahaan, baik yang tertulis maupun tidak. Sedangkan menurut Siagian (2013) mengemukakan disiplin adalah "suatu bentuk pelatihan yang berusaha memperbaiki dan membentuk pengetahuan, sikap dan perilaku pegawai sehingga para pegawai tersebut secara sukarela berusaha bekerja kooperatif dengan para pegawai yang lain serta meningkatkan prestasi kerja". Selanjutnya menurut Davis (2007), bahwa "Dicipline is management action to enforce organization standars". (disiplin kerja dapat diartikan sebagai pelaksanaan manajemen untuk memperteguh pedoman-pedoman organisasi). Menurut Sutrisno, (2016) menyampaikan disiplin kerja adalah "perilaku seseorang yang sesuai dengan peraturan, prosedur kerja yang ada atau disiplin adalah sikap, tingkah laku dan perbuatan yang sesuai dengan peraturan dari organisasi baik tertulis maupun yang tidak tertulis". Kemudian menurut Rivai (2014) disiplin kerja adalah "suatu alat yang dipergunakan para manajer untuk berkomunikasi dengan karyawan agar mereka bersedia untuk mengubah suatu perilaku serta sebagai suatu upaya untuk meningkatkan kesadaran dan kesediaan seorang dalam memenuhi segala peraturan perusahaan".

Berdasarkan uraian tersebut dapat disimpulkan bahwa disiplin kerja merupakan sebuah konsep dan aturan dalam organisasi atau perusahaan untuk menuntut kesediaan anggotanya berlaku teratur dan mentaati aturan-aturan yang telah ditetapkan pada suatu organisasi atau perusahaan.

Adapun tujuan disiplin adalah untuk meningkatkan produktivitas secara efisien, dan proses pendisiplinan 
karyawan dapat dilakukan dengan cara, yaitu menurut Arifin dan Fauzi (2007): 1). "Tindakan yang bersifat positif, antara lain: a). Hendaknya bersifat membangun. b). Hendaknya pendidikan diri dilakukan secara pribadi. $\quad$ c). Hendaknya dilakukan dengan segera. 2). Tindakan yang bersifat negatif, antara lain: a). Penurunan jabatan.

Dirumahkan sementara. c). Pemberian surat peringatan. d). Pemberian sangsi administrasi lainnya, seperti penundaan naikgaji, pangkat, dan lain-lain”.

Menurut Hasibuan (2017), ada beberapa faktor yang bisa mempengaruhi tingkat disiplin kerja, diantaranya yaitu: 1). "Tujuan dan Kemampuan; Tujuan dan kemampuan ikut mempengaruhi tingkat kedisiplinan karyawan. Tujuan yang akan dicapai harus jelas dan ditetapkan secara ideal juga cukup menantang bagi kemampuan karyawan. Hal ini berarti tujuan (pekerjaan) yang dibebankan kepada karyawan harus sesuai dengan kemampuan karyawan bersangkutan, agar dia bekerja sungguh-sungguh dan disiplin dalam mengerjakannya.

2).

Kepemimpinan; Kepemimpinan sangat berperan dalam menentukan kedisiplinan karyawan, karena pimpinan dijadikan teladan dan panutan oleh para bawahannya. Pimpinan harus mencontohkan perilaku yang baik agar ditiru oleh bawahannya. Seorang Pemimpin jangan mengharapkan kedisiplinan bawahannya akan baik, jika dia pun tak mampu mencontohkan perilaku disiplin yang baik kepada bawahannya. 3). Balas Jasa; Balas jasa berupa gaji dan kesejahteraan ikut mempengaruhi kedisiplinan karyawan karena balas jasa akan memberikan kepuasan dan kecintaan karyawan terhadap perusahaan/pekerjaannya. Apabila kecintaan karyawan semakin baik terhadap pekerjaan, kedisiplinan mereka akan semakin baik pula.

4).

Keadilan; Keadilan ikut mendorong terwujudnya kedisiplinan karyawan, karena ego dan sifat manusia yang selalu merasa dirinya penting dan minta diperlakukan sama dengan manusia lainnya. Dengan keadilan yang baik akan menciptakan kedisiplinan yang baik pula. Jadi, keadilan harus diterapkan dengan baik pada setiap perusahaan supaya kedisiplinan karyawan perusahaan baik pula. 5). Waskat; Waskat (pengawasan melekat) yaitu tindakan nyata dan paling efektif dalam mewujudkan kedisiplinan karyawan perusahaan. Waskat efektif merangsang kedisiplinan dan moral kerja karyawan. Karyawan merasa mendapat perhatian, bimbingan, petunjuk, pengarahan, dan pengawasan dari atasannya. 6). Ketegasan; Ketegasan pimpinan dalam melakukan tindakan akan mempengaruhi kedisiplinan karyawan perusahaan. Pimpinan harus berani dan tegas, bertindak untuk menghukum setiap karyawan yang indisipliner sesuai dengan sanksi hukuman yang telah ditetapkan. Ketegasan pimpinan menegur dan menghukum setiap karyawan yang indisipliner akan mewujudkan kedisiplinan yang baik pada perusahaan tersebut. 7). Sanksi; Dengan sanksi hukuman yang semakin berat, karyawan akan semakin takut melanggar peraturan perusahaan, sikap, perilaku indisipliner karyawan akan berkurang".

Indikator disiplin kerja karyawan menurut Dharma (2012) adalah: 1). "Kehadiran karyawan setiap hari: karyawan wajib hadir di perusahaannya sebelum jam kerja, dan pada biasanya digunakan saran kartu kehadiran pada mesin absensi. 2). Ketepatan jam kerja: penetapan hari kerja dan jam kerja diatur atau ditentukan oleh perusahaan. Karyawan diwajibkan untuk mengikuti aturan jam kerja, tidak melakukan pelanggaran jam isitirahat dan jadwal kerja lain, keterlambatan masuk kerja, dan wajib mengikuti aturan jam kerja per hari. 3). Mengenakan pakaian kerja dan tanda pengenal: seluruh karyawan wajib memakai pakaian yang rapi dan sopan, 
dan mengenakan tanda pengenal selama menjalankan tugas kedinasan. Bagi sebagian besar perusahaan biasanya menyediakan pakaian seragam yang sama untuk semua karyawannya sebagai bentuk simbol dari kebersamaan dan keakraban di sebuah perusahaan. 4). Ketaatan karyawan terhadap peraturan: adakalanya karyawan secara terangterangan menunjukkan ketidakpatuhan, seperti menolak melaksanakan tugas yang seharusnya dilakukan. Jika tingkah laku karyawan menimbulkan dampak atas kinerjanya, para pemimpin harus siap melakukan tindakan pendisiplinan".

\section{Lingkungan Kerja}

Lingkungan Kerja adalah kehidupan sosial, psikologi dan fisik yang berpengaruh terhadap pekerjaan dan menjalankan tugasnya. Kehidupan manusia tidak terlepas dari berbagai keadaan lingkungan yang ada disekitarnya, antara manusia dan lingkungan memiliki hubungan yang erat.

Menurut Sedarmayati, (2017) Lingkungan Kerja adalah "keseluruhan alat perkakas dan bahan yang dihadapi, lingkungan sekitarnya dimana seseorang bekerja, metode kerjanya, serta pengaturan kerjanya baik sebagai perseorangan maupun sebagai kelompok". Sedang menurut Saydam (2011) juga menyebutkan bahwa lingkungan kerja merupakan kseeluruhan sarana dan prasarana kerja yang ada di sekitar karyawan yang sedang melakukan pekerjaan yang dapat mempengaruhi pelaksanaan pekerjaan itu sendiri.

$$
\text { Menurut Sunyoto }
$$

lingkungan kerja adalah "segala sesuatu yang ada di sekitar para pekerja dan yang dapat mempengaruhi dirinya dalam menjalankan tugas-tugas yang dibebankan". Kemudian lingkungan kerja menurut Afandi (2018) adalah "sesuatu yang ada dilingkungan para pekerja yang dapat mempengaruhi dirinya dalam menjalankan tugas seperti temperatur, kelembaban, pentilasi, penerangan, kegaduhan, kebersihan tempat kerja, dan memadai tidaknya alat-alat perlengkapan kerja". Lingkungan kerja dapat diartikan "sebagai keseluruhan alat perkakas yang dihadapi, lingkungan sekitarnya dimana seorang pekerja, metode kerjanya, sebagai pengaruh kerjanya baik sebagai perorangan maupun sebagai kelompok".

Dari uraian tersebut dapat disimpulkan bahwa lingkunngan kerja adalah suatu tempat yang berada di sekitar pegawai baik fisik maupun non fisik diwiayah organisasi, lingkungan dapat mempengaruhi produktivitas kerja karyawan. Lingkungan kerja juga mencakup interaksi atau hubungan antara karyawan dan pimpinan organisasi.

$$
\text { Menurut Siagian }
$$
menyatakan bahwa secara garis besar, lingkungan kerja terdapat dua jenis yaitu: 1). "Lingkungan Kerja Fisik; Lingkungan kerja fisik adalah semua keadaan berbentuk fisik yang terdapat disekitar tempat kerja dan dapat mempengaruhi karyawan. Ada beberapa kondisi fisik dari tempat kerja yang baik yaitu: a). Bangunan tempat kerja disamping menarik untuk dipandang juga dibangun dengan pertimbangan keselamatan kerja. b). Tersedianya peralatan kerja yang memadai. c). Tersedianya tempat istirahat untuk melepas lelah, seperti kafetaria baik dalam lingkungan perusahaan atau sekitarnya yang mudah dicapai karyawan. d). Tersedianya tempat ibadah keagamaan seperti masjid dan musholla untuk karyawan. e). Tersedianya sarana angkutan, baik yang diperuntukkan karyawan maupun angkutan umum yang nyaman, murah dan mudah di peroleh. 2). Lingkungan Kerja Non Fisik; Lingkungan kerja non fisik adalah lingkungan kerja yang menyenangkan dalam arti terciptanya hubungan kerja yang harmonis antara karyawan dan atasan, karena pada hakekatnya manusia dalam bekerja tidak hanya mencari uang saja, akan tetapi bekerja merupakan bentuk 
aktivitas yang bertujuan untuk mendapatkan kepuasan".

Dari beberapa pendapat tersebut dapat disimpulkan bahwa lingkungan kerja fisik merupakan keadaan berbentuk fisik yang mencakup setiap hal dari fasilitas organisasi yang dapat memepengaruhi karyawan dalam melaksanakan pekerjaan atau efektivitas. Sedangkan lingkungan kerja non fisik merupakan keadaan disekitar tempat kerja yang bersifat non fisik. Lingkungan kerja non fisik tidak dapatdi tangkap oleh panca indera manusia, namun dapat dirasakan oleh perasaan misalnya, hubungan antara karyawan dengan pimpinan.

Menurut Ishak dan Tanjung (2013), manfaat lingkungan kerja yaitu "menciptakan gairah kerja, sehingga produktivitas dan prestasi kerja meningkat". Sementara itu, manfaat yang didapatkan karena bekerja dengan orang yang termotivasi yakni pekerjaan bisa terselesaikan dengan tepat, itu artinya pekerjaan diselesaikan sesuai standar yang benar dan dalam skala waktu yang ditentukan. Prestasi kerjanya akan dipantau oleh individu yang bersangkutan, dan tidak akan mengakibatkan terlalu banyak pengawasan serta semangat juang akan tinggi.

Indikator lingkungan kerja fisik, menurut Sedarmayanti (2017) indikatorindikator lingkungan kerja fisik, diantaranya: 1). "Pencahayaan di ruang kerja; Pencahayaan yang cukup tetapi tidak menyilaukan akan membantu menciptakan kinerja karyawannya. 2). Sirkulasi udara di ruang kerja; Sirkulasi udara yang baik akan menyehatkan badan. Sirkulasi udara yang cukup dalam ruangan kerja sangat diperlukan apabila ruangan tersebut penuh dengan karyawan. 3). Kebisingan; Kebisingan mengganggu konsentrasi, siapapun tidak senang mendengarkan suara bising, karena kebisingan merupakan gangguan terhadap seseorang. 4). Penggunaan warna; Warna dapat dipengaruhi terhadap jiwa manusia, sebenarnya bukan warna saja yang diperhatikan tetapi komposisi warna pun harus pula diperhatikan. 5). Kelembaban udara; Kelembaban adalah banyaknya air yang terkandung dalam udara, biasanya dinyatakan dalah persentase. Kelembaban ini berhubungan atau dipengaruhi oleh temperatur udara. 6). Musik di tempat kerja; Musik mampu merangsang dan membangkitkan karyawan dalam melakukan pekerjaan jika memiliki nada lembut, sesuai dengan waktu, tempat dan suasana. 7). Keamanan di Tempat Kerja; Faktor keamanan dalam tempat kerja perlu diperhatikan untuk tetap menjaga rasa tenang dan aman saat bekerja. Pemanfaatan SATPAM (Satuan Petugas Keamanan) dan konstruksi gedung yang layak untuk ditempati karyawan dapat meningkatkan rasa aman".

Indikator lingkungan kerja non fisik, menurut Sedarmayanti (2017), lingkungan kerja non fisik perusahaan dapat berupa: 1). "Hubungan kerja antara pimpinan dan bawahan; Terciptanya komunikasi yang baik, sikap menghormati dan patuh pada hubungan kerja antara pimpinan dan bawahan, maka tujuan perusahaan akan mudah tercapai. 2). Hubungan kerja antara rekan kerja; Terciptanya hubungan antara rekan kerja yang baik, maka kerja sama dalam tim dapat berjalan dengan mudah".

\section{Kinerja Karyawan}

Kinerja dapat diartikan "sebagai hasil pencapaian sesuai dengan standart yang berlaku pada organisasi. Kinerja adalah hasil-hasil fungsi pekerjaan seseorang atau kelompok dalam suatu organisasi pada periode waktu tertentu yang merefleksikan seberapa baik seseorang atau kelompok tersebut memenuhi persyaratan sebuah pekerjaan dalam usaha pencapaian tujuan organisasi". (Bernardin dan Russell, 2008). Menurut Sutrisno (2016), kinerja adalah "kesuksesan seseorang dalam melaksanakan tugas, hasil kerja yang 
dapat dicapai oleh seseorang atau sekelompok orang dalam suatu organisasi sesuai dengan wewenang dan tanggung jawab masing-masing atau tentang bagaimana seseorang diharapkan dapat berfungsi dan berperilaku sesuai dengan tugas yang telah dibebankan kepadanya serta kuantitas, kualitas dan waktu yang digunakan dalam menjalankan tugas". Sedangakn menurut Afandi (2018) Kinerja adalah "hasil kerja yang dapat dicapai oleh seseorang atau kelompok orang dalam suatu perusahaan sesuai dengan wewenang dan tanggung jawab masing-masing dalam upaya pencapaian tujuan organisasi secara illegal, tidak melanggar hukum dan tidak bertentangan dengan moral dan etika". Selanjutnaya menurut Mangkunegara (2017) kinerja karyawan adalah "hasil kerja secara kualitas dan kuantitas yang dicapai oleh seseorang karyawan dalam melaksanakan tugasnya sesuai dengan tanggung jawab yang diberikan kepadanya".

Dari beberapa pengertian tentang kinerja tersebut, dapat disimpulkan bahwa kinerja adalah prestasi atau hasil kerja baik kualitas maupun kuantitas yang dicapai sumber daya manusia dalam melaksanakan tugasnya sesuai dengan standart dan tanggung jawab yang diberikan kepadanya.

Penilaian kinerja karyawan secara umum memberikan berbagai manfaat bagi kedua pihak yaitu organisasi maupun karyawan. Berikut manfaat penilaian kinerja karyawan menurut Rivai, (2014) yang perlu diketahui: 1). "Memberikan informasi mengenai hasil-hasil yang diinginkan dari suatu pekerjaan. 2). Mencegah adanya miskomunikasi terkait kualitas kerja yang diharapkan. 3). Menciptakan peningkatan produktivitas karyawan dikarenakan adanya feedback/reward bagi karyawan yang berprestasi. 4). Menghargai setiap kontribusi. 5). Menciptakan komunikasi dua arah antara pihak manajer dengan karyawan".
Mahmudi (2015) menyatakan bahwa faktor yang mempengaruhi kinerja adalah sebagai berikut: 1). "Faktor yang individual, meliputi: pengetahuan, keterampilan, kemampuan, kepercayaan diri, motivasi dan komitmen yang dimiliki oleh setiap individu. 2). Faktor kepemimpinan, meliputi: kualitas dalam memberikan dorongan, semangat, arahan dan dukungan yang diberikan manajer dan team leader. 3). Faktor tim, meliputi: kualitas dukungan dan semangat yang di berikan oleh rekan dalam suatu tim, kepercayaan terhadap sesama anggota tim, kekompakan dan keeratan tim. 4). Faktor sistem, meliputi: sistem kerja, fasilitas kerja atau insfrastruktur yang diberikan oleh organisasi, proses organisasi dan kultur kinerja dalam organisasi. 5). .Faktor kontekstual (situasional), meliputi tekanan dan perubahan lingkungan eksternal dan internal".

Indikator untuk mengukur kinerja karywan secara individu ada lima indikator yaitu Robbins, (2007). 1). "Kualitas, kualitas kerja diukur dari persepsi karyawan terhadap kualitas pekerjaan yang dihasilkan serta kesempurnaan tugas terhadap keterampilan dan kemampuan karyawan. 2). Kuantitas merupakan jumlah yang dihasilkan dinyatakan dalam istilah seperti jumlah unit, jumlah siklus aktivitas yang diselesaikan. 3). Ketepatan waktu, merupakan tingkat aktivitas diselesaikan pada awal waktu yang dinyatakan, dilihat dari sudut koordinasi dengan hasil output serta memaksimalkan waktu yang tersedia untuk aktivitas lain. 4). Efektivitas merupakan tingkat penggunaan sumber daya organisasi "tenaga, uang teknologi, bahan baku" dimaksimalkan dengamn maksud menaikkan hasil dari setiap unit dalam penggunaan sumber daya. 5). Kemandirian, merupakan tingkat seorang karyawan yang nantinya akan dapat menjalankan fungsi kerjanya Komitmen kerja. Merupakan suatu tingkat 
dimana karyawan mempunyai komitmen kerja dengan instansi dan tanggung jawab karyawan terhadap kantor".

\section{METODE PENELITIAN}

Penelitian ini termasuk dalam kategori penelitian asosiatif kausal dengan menggunakan pendekatan kuantitatif. Populasi dalam penelitian ini adalah seluruh karyawan PT. Bank BCA KCP Citra Towers Kemayoran yang berjumlah 30 orang. Sampel menggunakan teknik sampling jenuh, semua anggota populasi dijadikan sampel, karena jumlah reltif sedikit, sedangkan metode analisa data dengan menggunakan regresi linear sederhana dan berganda.

\section{HASIL PENELITIAN DAN PEMBAHASAN}

\section{Hasil Penelitian}

\section{Uji instrumen data}

Berdasarkan uraian tersebut di atas, maka untuk dapat menentukan apakah variabel disiplin kerja dan lingkungan kerja dapat dijadikan pengukur terhadap kinerja karyawan PT. Bank BCA KCP Citra Towers Kemayoran. Namun sebelumnya data diolah terlebih dahulu dan dilakukan pengujian terhadap varibel yang digunakan yaitu disiplin kerja,

lingkungan kerja dan kinerja karyawan untuk mengetahui apakah data tersebut akurat dan dapat dipercaya.

\section{Uji validitas}

Pengujian validitas ini dilakukan untuk menguji apakah tiap butir pernyataan telah mewakili indikator yang akan diteliti, persyaratan minimum untuk dapat dikatakan valid adalah $r=0,30$. Jadi, apabila korelasi antara butir-butir item pernyataan dengan skor total kurang dari 0,30, maka butiran dalam instrumen tersebut dapat dikatakan tidak valid. Uji validitas dilakukan dengan melihat korelasi antara skor masing-masing item pernyataan dengan skor total. (Sugiyono, 2018).

Dari perhitungan koefisien korelasi skor tiap butir pernyataan dari 30 responden tentang instrumen disiplin kerja, dengan jumlah 8 butir pernyataan; instrumen lingkungan kerja 9 butir pernyataan dan instrumen kinerja karyawan 10 butir pernyataan dengan total skor setiap responden diperoleh hasil $r$ hitung lebih besar dari $\mathrm{r}$ kritis $=0,30$, maka seluruh item pernyataan didapatkan menunjukkan hasil yang valid.

\section{Uji reliabilitas}

Pengujian reliabilitas ini dilakukan untuk menguji seberapa jauh hasil pengukuran yang dapat diandalkan secara konsisten. Pada tabel hasil pengujian reliabilitas reliabilitas berikut, diketahui bahwa semua variabel mempunyai alpha di atas 0,6 yang berarti bahwa semua variabel dalam penelitian ini dapat diandalkan.

Tabel 1: Hasil Uji Reliabilitas

\begin{tabular}{lccc}
\hline \multicolumn{1}{c}{ Variabel } & $\begin{array}{c}\text { Cronbach } \\
\text { Alpha }\end{array}$ & $\begin{array}{c}\text { Nilai kritis } \\
(\boldsymbol{\alpha})=\mathbf{5 \%}\end{array}$ & Keterangan \\
\hline Disiplin Kerja & 0.629 & 0.600 & Reliabel \\
Lingkungan Kerja & 0.684 & 0.600 & Reliabel
\end{tabular}


$\begin{array}{llll}\text { Kinerja Karyawan } & 0.609 & 0.600 & \text { Reliabel }\end{array}$

Sumber: Data Primer, diolah tahun 2021

Berdasarkan angka-angka reliabilitas cronbach alpha tersebut tampak bahwa seluruh pernyataan yang ada membentuk ukuran yang reliabel, yaitu disiplin kerja, lingkungan kerja, dan kinerja karyawan membentuk ukuran yang reliabel dari masing-masing variabel.

\section{Analisis regresi linear sederhana}

Tabel 2: Pengaruh Disiplin Kerja Terhadap Kinerja Karyawan PT. Bank BCA KCP Citra Towers Kemayoran

\begin{tabular}{lcccccc}
\hline \multirow{2}{*}{ Variabel } & $\mathbf{R}$ & $\mathbf{R}$ & Ponstanta & Koefisien & Sig & $\boldsymbol{\alpha}$ \\
\cline { 2 - 6 } Square & & Regresi & & \\
\hline Disiplin Kerja & 0,764 & 0,584 & 10,663 & 0,931 & 0,000 & 0.01 \\
\hline Pengujian Signifikan \\
\hline t hitung > t tabel =6,267 > 2,048 \\
\hline Keterangan: Variabel Kinerja_Karyawan \\
Sumber: data diolah 2021
\end{tabular}

Tabel 2, nilai koefisien determinasi $\left(\mathrm{R}^{2}\right)$ sebesar 0.584 , artinya disiplin kerja memberikan kontribusi sebesar 58,4\% kepada kinerja karyawan PT. Bank BCA KCP Citra Towers Kemayoran, sedangkan sisanya sebesar $41,6 \%$ disumbangkan faktor lain yang tidak diteliti.

Persamaan regresi
$\mathrm{Y}=10,663+0,931\left(\mathrm{X}_{1}\right)$

Disiplin kerja berpengaruh positif dan signifikan pada tingkat nyata $99 \%$ terhadap kinerja karyawan PT. Bank BCA KCP Citra Towers Kemayoran. Koefisien disiplin kerja sebesar 0,931, artinya jika ada peningkatan disiplin kerja, maka kinerja karyawan PT. Bank BCA KCP Citra Towers Kemayoran akan meningkat.

Tabel 3: Pengaruh Lingkungan Kerja Terhadap Kinerja Karyawan PT. Bank BCA KCP Citra Towers Kemayoran

\begin{tabular}{|c|c|c|c|c|c|c|}
\hline \multirow[b]{2}{*}{ Variabel } & \multicolumn{6}{|c|}{ Parameter } \\
\hline & $\mathbf{R}$ & $\begin{array}{c}\mathbf{R} \\
\text { Souare }\end{array}$ & Konstanta & $\begin{array}{c}\text { Koefisien } \\
\text { Reoresi }\end{array}$ & Sig & $\alpha$ \\
\hline Lingkungan Kerja & 0,810 & 0,656 & 9,060 & 0,890 & 0,000 & 0.01 \\
\hline \multicolumn{7}{|c|}{ Pengujian Signifikan } \\
\hline $\mathrm{t}$ hitung $>\mathrm{t}$ tabel $=$ & $305>$ &, 048 & & & & \\
\hline
\end{tabular}

Keterangan: Variabel Kinerja_Karyawan

Sumber: data diolah 2021

Tabel 3, nilai koefisien determinasi $\left(\mathrm{R}^{2}\right)$ sebesar 0.656, artinya lingkungan kerja memberikan kontribusi sebesar 65,6\% kepada variabel kinerja karyawan PT. Bank BCA KCP Citra Towers Kemayoran, sedangkan sisanya sebesar
$34,4 \%$ disumbangkan faktor lain yang tidak diteliti.

Persamaan regresi

$\mathrm{Y}=9,060+0,890\left(\mathrm{X}_{2}\right)$ 
Lingkungan kerja berpengaruh positif dan signifikan pada tingkat nyata 99\% terhadap kinerja karyawan PT. Bank BCA KCP Citra Towers Kemayoran. Koefisien lingkungan kerja sebesar 0,890, artinya jika ada peningkatan lingkungan kerja, maka kinerja karyawan PT. Bank BCA KCP Citra Towers Kemayoran akan meningkat.

\section{Analisis regresi linear berganda}

\begin{tabular}{|c|c|c|c|c|c|c|}
\hline \multirow[b]{2}{*}{ Variabel } & \multicolumn{6}{|c|}{ Parameter } \\
\hline & $\begin{array}{c}\text { Mult. } \\
\text { R }\end{array}$ & $\begin{array}{c}\mathbf{R} \\
\text { Square }\end{array}$ & Konstanta & $\begin{array}{c}\text { Koefisien } \\
\text { Regresi }\end{array}$ & Sig. & $\alpha$ \\
\hline $\begin{array}{l}\text { Disiplin Kerja } \\
\text { Lingkungan Kerja }\end{array}$ & 0,868 & 0,754 & 3,149 & $\begin{array}{l}0,502 \\
0,596\end{array}$ & $\begin{array}{l}0,003 \\
0,000\end{array}$ & 0,01 \\
\hline \multicolumn{7}{|c|}{ Pengujian Signifikan } \\
\hline $\mathrm{F}$ hitung $>\mathrm{F}$ tabel & $=41,379$ & $>3,354$ & & & 0,000 & \\
\hline
\end{tabular}

\section{Keterangan: Variabel Kinerja_Karyawan}

Sumber: data diolah 2021

Tabel 4, Nilai $F$ hitung sebesar 41,379, artinya secara bersama-sama disiplin kerja dan lingkungan kerja berpengaruh signifikan pada tingkat nyata 99\% terhadap kinerja karyawan PT. Bank BCA KCP Citra Towers Kemayoran. Nilai koefisien determinasi $\left(\mathrm{R}^{2}\right)$ sebesar 0.754 , artinya variabel disiplin kerja dan lingkungan kerja memberikan kontribusi sebesar 75,4\% kepada variabel kinerja karyawan PT. Bank BCA KCP Citra Towers Kemayoran, sedangkan sisanya sebesar 24,6\% disumbangkan faktor lain yang tidak dibahas dalam penelitian ini.

Persamaan regresi

$\mathrm{Y}=3,149+0,502\left(\mathrm{X}_{1}\right)+0,596\left(\mathrm{X}_{2}\right)$

Disiplin kerja dan lingkungan kerja berpengaruh signifikan terhadap kinerja karyawan PT. Bank BCA KCP Citra Towers Kemayoran pada tingkat nyata 99\%. Koefisien disiplin kerja sebesar 0,502 artinya jika ada peningkatan disiplin kerja, maka kinerja karyawan PT. Bank BCA KCP Citra Towers Kemayoran akan meningkat dengan asumsi lingkungan kerja tidak berubah. Koefisien lingkungan kerja sebesar 0,596, artinya jika ada peningkatan lingkungan kerja, maka kinerja karyawan PT. Bank BCA KCP Citra Towers Kemayoran akan meningkat dengan asumsi disiplin kerja tidak berubah.

\section{Pembahasan}

\section{Pengaruh Disiplin Kerja Terhadap Kinerja Karyawan PT. Bank BCA KCP Citra Towers Kemayoran}

Berdasarkan hasil penelitian menunjukan bahwa adanya peningkatan disiplin kerja mendorong meningkatkan kinerja karyawan. Hal ini dikarenakan bahwa karyawan selalu hadir sebelum jam kerja, absen yang digunakan dengan kartu absensi pada mesin absensi, jam kerja diatur oleh perusahaan, karyawan wajib mengikuti aturan jam kerja, karyawan berpenampilan rapih dan sopan, wajib menggunakan tanda pengenal selama menjalankan tugas, taat terhadap aturan perusahaan, dan patuh terhadap perintah atasan. Hasil penelitian ini sejalan dengan hasil penelitian yang dilakukan Pratiwi, et al, (2017) dan Wulandari, et al, (2018) yang menyatakan bahwa disiplin kerja berpengaruh positif dan signifikan 
terhadap kinerja karyawan. Dengan demikian hipotesis pertama dapat diterima.

\section{Pengaruh Lingkungan Kerja Terhadap Kinerja Karyawan PT. Bank BCA KCP Citra Towers Kemayoran}

Berdasarkan hasil penelitian menyatakan bahwa adanya peningkatan lingkungan kerja akan mendorong meningkatkan kinerja karyawan. Hal ini dikarenakan bahwa pencahayaan di ruang kerja cukup membantu menciptakan kinerja karyawan, sirkulasi udara dala mruangan kerja cukup baik, komposisi warna di ruangan membuat nyaman dalam bekerja, kelembaban udara yang dirasakan dapat berdampak pada kinerja, musik yang lembut mampu membangkitkan suasan dalam bekerja, keamanan ditempat kerja sangat diperhatikan, adanya hubngan yang baik antara rekan kerja untuk mendukung penyelesaian pekerjaan, dan terciptanya komunikasi yang baik antara pimpinan dan bawahan. Hasil penelitian ini sejalan dengan hasil penelitian yang dilakukan Yudiningsih, et al, (2016) dan Ferawati, (2017) yang menyatakan bahwa lingkungan kerja berpengaruh positif dan signifikan terhadap kinerja karyawan. Dengan demikian hipotesis kedua dapat diterima.

\section{Pengaruh Disiplin Kerja dan Lingkungan Kerja Terhadap Kinerja Karyawan PT. Bank BCA KCP Citra Towers Kemayoran}

Berdasarkan hasil penelitian diketahui bahwa disiplin kerja dan lingkungan kerja mendukung peningkatan kinerja karyawan PT. Bank BCA KCP Citra Towers Kemayoran. Hasil penelitian ini sama dengan hasil penelitian yang dilakukan Pratiwi, et al, (2017), Wulandari, et al, (2018), Yudiningsih, et al, (2016) dan Ferawati, (2017), yang menyatakan bahwa disiplin kerja dan lingkungan kerja berpengaruh terhadap kinerja karyawan. Dengan demikian hipotesis ketiga dapat diterima.

\section{KESIMPULAN DAN SARAN}

\section{Kesimpulan}

Kesimpulan dalam penelitian ini adalah sebagai berikut: 1). Disiplin kerja mendorong peningkatan kinerja karyawan PT. Bank BCA KCP Citra Towers Kemayoran. 2). Lingkungan kerja mendorong peningkatan kinerja karyawan PT. Bank BCA KCP Citra Towers Kemayoran. 3). Disiplin kerja dan lingkungan kerja mendorong peningkatan kinerja karyawan PT. Bank BCA KCP Citra Towers Kemayoran.

\section{Saran}

Saran dan masukan yang dapat penulis berikan terhadap objek yang diteliti yaitu PT. Bank BCA KCP Citra Towers Kemayoran adalah sebagai berikut: 1). Disiplin kerja karyawan relatif sudah baik, hampir semua aturan yang diterapkan dapat dipatuhi oleh para karyawan, walaupun masih ada satu atau dua orang karyawan yang kurang disiplinnya, dan untuk itu manajemen terus meningkatkan disiplin kerja para karyawannya, hal ini perlu kiranya manajemen memperhatikan keinginan dan keluhan yang terjadi pada karyawan, penting untuk diperhatikan agar mereka tetap menjaga disiplin kerja yang sudah ada. 2). Bank agar lebih memperhatikan kondisi lingkungan kerja fisik maupun non fisik. Bank perlu lebih meningkatkan dan mengutamakan kondisi lingkungan kerja terutama pada keamanan dan kenyamanan karyawan, kondisi peralatan kerja karyawan, dan memastikan apakah hubungan antara karyawan satu dengan karyawan lainnya baik-baik saja. 3). Penelitian ini menggunakan dua variabel bebas untuk mengukur kinerja, sehingga disarankan bagi penelitian selanjutnya untuk mengembangkan dengan variabel lainnya seperti motivasi, beban kerja dan variabel lainnya yang lebih relevan yang memiliki pengaruh terhadap kinerja 
karyawan sehingga dapat membantu tercapainya tujuan perusahaan Bank BCA KCP Citra Towers Kemayoran.

\section{DAFTAR PUSTAKA}

Afandi, P. 2018. Manajemen Sumber Daya Manusia (Teori, Konsep dan Indikator). Riau: Zanafa Publishing.

Arifin, Johar dan Fauzi, A. 2007. Aspek Kuantitatif Manajemen Sumber Daya Manusia. Jakarta: Elex Media Komputindo Indonesia.

Bernardin, H.J. dan Russel, J.E.A. 2008. Human Resource Management Anexperiental Approach. Singapore: Mc Graw-Hill, Inc.

Davis, Keith. 2007. Perilaku Dalam Organisasi. Edisi Ketujuh. Alih Bahasa, Agus Dharma. Jakarta: Erlangga.

Dharma, Surya. 2012. Manajemen Kinerja Falsafah Teori dan Penerapannya. Yogyakarta: Pustaka Pelajar.

Ferawati, Apfia. 2017. "Pengaruh Lingkungan Kerja dan Disiplin Kerja Terhadap Kinerja Karyawan PT Cahaya Indo Persada Surabaya". Jurnal Agora Vol. 5, No. 1 (2017. Hal. 1-3.

Hasibuan, Malayu S.P. 2017. Manajemen Sumber Daya Manusia. Jakarta: PT. Bumi Aksara.

Ishak, Arep dan Tanjung, Hendri. 2013. Manajemen Sumber Daya Manusia. Jakarta: Penerbit Universitas Trisakti.

Mahmudi. 2005. Manajemen Kinerja Sektor Publik. Yogyakarta: UPP AMPYKPN.

Mangkunegara, Anwar Prabu. 2017. Manajemen Sumber Daya Manusia Perusahaan, Cetakan Kesepuluh, Bandung: PT. Remaja Rosdakarya.

Pratiwi, Dian., Lie, Darwin dan Chandra, Erbin. 2017. "Pengaruh Disiplin Kerja dan Lingkungan Kerja Terhadap Kinerja Pegawai Pada PT
Bank Sumut Syariah Cabang Pematangsiantar". Jurnal Maker. Vol. 3 No. 1, Juni 2017. ISSN: 2502-4434. Hal. 73-81.

Rivai, Veithzal, 2014. Manajemen Sumber Daya Manusia untuk Perusahaan : dari Teori Ke Praktik, Edisi Pertama, Depok: Penerbit PT. Raja Grafindo Persada.

Robbins, Stephen.P. 2007. Perilaku Organisasi. Jakarta: PT. Indeks Gramedia.

Saydam, Gouzaly. 2011. Manajemen Sumber Daya Manusia. Jakarta: Gunung Agung.

Sedarmayanti. 2017. Manajemen Sumber Daya Manusia. Bandung: PT. Refika Aditama.

Siagian, Sondang P. 2013. Manajemen Sumber Daya Manusia. Jakarta: Bumi Aksara.

Simamora, Henry. 2012. Manajemen Sumber Daya Manusia. Edisi 1. Yogyakarta: STIE YKPN Yogyakarta.

Sugiyono. 2018. Statikstika Untuk Penelitian. Bandung: Alfabeta.

Sunyoto, Danang. 2012. Manajemen Sumber Daya Manusia. Jakarta: PT Buku Seru.

Sutrisno, Edy 2016, Manajemen Sumber Daya Manusia, Cetakan Kedelapan, Jakarta: Prenamedia Group.

Wulandari, Lastri Shofya., Abdurrahman, Dudung dan Bayuni, Eva Misfah. 2018 "Pengaruh Disiplin Kerja dan Lingkungan Kerja Terhadap Kinerja Karyawan di Bank BRI Syariah KCI Citarum Bandung". Prosiding Keuangan dan Perbankan Syariah. Volume 4, No. 1 Tahun 2018. Hal. 140-146.

Yudiningsih, Ni Made Diah., Yudiaatmaja, Fridayana dan Yulianthini, Ni Nyoman. 2016. "Pengaruh Lingkungan Kerja dan Disiplin Kerja Terhadap Kinerja Pegawai Pada Distanak Kabupaten Buleleng". E-Journal Bisma 
Universitas Pendidikan Ganesha

Jurusan Manajemen (Volume 4

Tahun 2016). Hal. 1-7. 